\title{
Konsep Evaluasi Dalam Pembelajaran Pendidikan Islam
}

\author{
SAWALUDDIN \\ Sekolah Tinggi Agama Islam (STAI) Rokan Bagan Batu Rokan Hilir \\ Jl. Lintas Riau-Sumut Km. 6 BahteraMakmur,BaganBatu Riau, Indonesia \\ E-mail: regarsawaluddin@gmail.com
}

\begin{abstract}
Evaluation in Islamic education is generally very useful for educators, learners, thinkers of Islamic education, politics of Islamic education policy makers, to assist them in improving the supervisory system and considering the policies that will be applied in the national education system (Islam). Research Library or Library research is the study of several references related to research conducted both the thinking of the figures and others. evaluation is a process and action planned to collect information about progress, growth and development (learners) of the purpose (education), so that can be compiled assessment that can be used as a basis for making decisions. Evaluations are conducted to evaluate learners, educators, educational materials, the process of delivering subject matter, and various other aspects related to educational materials.
\end{abstract}

\section{Keywords: The Concept Of Evaluation In Learning Islamic Education}

Abstrak: Evaluasi dalam pendidikan Islam, secara umumsangat berguna bagi pendidik, peserta didik, ahli fikir pendidikan Islam,politik pengambil kebijakan pendidikan Islam, untuk membantu mereka dalam membenahi sistem pengawasan dan mempertimbangkan kebijakan yang akan diterapkan dalam sistem pendidikan nasional (Islam). Penelitian Kepustakaan atau Library research adalah telaah kepada beberapa referensi yang berhubungan dengan penelitian yang dilakukan baik telaah pemikiran tokoh dan yang lainnya.evaluasi yaitu suatu proses dan tindakan yang terencana untuk mengumpulkan informasi tentang kemajuan, pertumbuhan dan perkembangan (peserta didik) terhadap tujuan (pendidikan), sehingga dapat disusun penilaiannya yang dapat dijadikan dasar untuk membuat keputusan. Evaluasi dilakukan untuk mengevaluasi peserta didik, pendidik, materi pendidikan, proses penyampaian materi pelajaran, dan berbagai aspek lainnya yang berkaitan dengan materi pendidikan.

Kata Kunci: Konsep, Evaluasi, Pembelajaran, Pendidikan Islam 


\section{PENDAHULUAN}

Proses pembelajaran merupakan tanggung jawab guru dalam mengembangkan segala potensi yang ada pada siswa. Salah satu komponen yang menjadi sasaran peningkatan kualitas pendidikan adalah sistem pembelajaran di kelas. Tujuan pokok proses pembelajaran adalah untuk mengubah tingkah laku siswa berdasarkan tujuan yang telah direncanakan dan disusun oleh guru sebelum proses kegiatan pembelajaran berlangsung. Perubahan tingkah laku itu mencakup aspek intelektual. Untuk menghasilkan dan mengetahui daya serap siswa terhadap pembelajaran yang dilakukan dan untuk mengetahui perubahan tingkah lakunya, maka evaluasi adalah salah hal yang sangat urgen untuk dilakukan. Sebab Evaluasi dipandang sebagai masukan yang diperoleh dari proses pembelajaran yang dapat dipergunakan untuk mengetahui kekuatan dan kelemahan berbagai komponen yang terdapat dalam suatu proses belajar mengajar (Prasetya Irawan, 2001:1).

\section{Pentingnyaevaluasi}

dalam pembelajaran, mengakibatkan seorang guru harus memiliki persiapan dan kompetensi yang baik, baik dari segi perencanaan pembelajaran, dan kemampuan guru mengembangkan proses pembelajaran serta penguasaannya terhadap bahan ajar, dan juga tidak cukup dengan kemampuan guru dalam menguasai kelas, tanpa diimbangi dengan kemampuan melakukan evaluasi terhadap perencanaan kompetensi siswa yang sangat menentukan dalam konteks perencanaan berikutnya, atau kebijakan perlakuan terhadap siswa terkait dengan konsep belajar tuntas (Purwanto, 2009: 3).
MAKNA EVALUASI, PENGUKURAN DAN PENILAIAN PEMBELAJARAN

\section{a. Evaluasi}

Makna evaluasi berasal dari bahasa Inggris, evaluation, yang lazim di artikan dengan makna penafsiran atau penilian. Yang kata kerjanya evaluate, di artikan menaksir (Evelina Siregar \& Hartini Nara, 2014141-142). Adapun makna evaluasi dalam bahasa arab disebut al-Thaqdir (التقديز) bermakna penilaian. Akar katanya adalah al-Qimah (القيمة) bermakna nilai. Dengan demikian secara harfiah evaluasi pembelajaran (Educational evaluation $=$ al-Taqdir al Tarbawy) diartikan sebagai penilaian dalam pendidikan atau penilaian mengenai hal-hal yang berkaitan dengan kegitan pendidikan dan pembelajaran (Anas Sudijono, 2009: 1).

Dalam Al-Qur'an terminologi evaluasi pendidikan terdapat beberapa makna dengan mengacu kepada makna kalimat;

\section{Al-Hisāb/al-Muhāsabah}

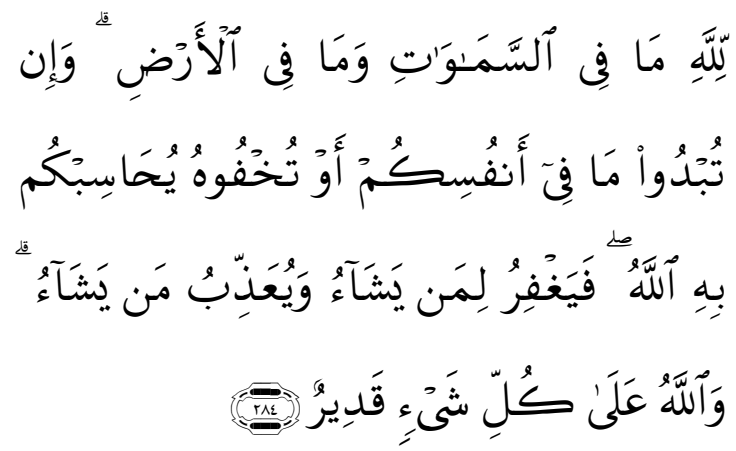

Artinya: Kepunyaan Allah-lah segala apa yang ada di langit dan apa yang ada di bumi. dan jika kamu melahirkan apa yang ada di dalam hatimu atau kamu menyembunyikan, niscaya Allah akan membuat perhitungan dengan kamu tentang perbuatanmu itu. Maka Allah mengampuni siapa yang dikehandaki-Nya dan menyiksa siapa yang dikehendaki-Nya; dan Allah Maha Kuasa atas segala sesuatu. (Q.S. alBaqarah: 284). 
Terma al-hisāb/al-muhāsabahi dianggap yang paling dekat dengan "حسب" kata evaluasi, berasal dari kata yang berarti menghitung. Al-Ghazali mempergunakan kata ini di dalam menjelaskan tentang evaluasi diri ( مدا yaitu suatu upaya mengoreksi dan menilai diri sendiri setelah melakukan aktivitas (Al-Ghazali, t.th: 391).

2. Al-Hukm

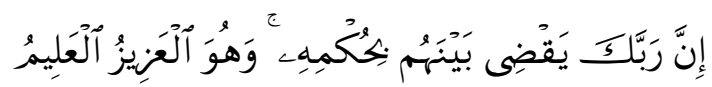

Artinya: Sesungguhnya Tuhanmu akan menyelesaikan perkara antara mereka dengan keputusan-Nya, dan Dia Maha Perkasa lagi Maha mengetahui. (Q.S. AL-Naml: 78).

\section{Al-Fitnah}

Secara bahasa al-fitnah adalah "الاختبار والتجريبة "yang berarti "الامتحان" pengujian dan eksperimen. Jika dikatakan "فنتت الذهب بالنار" maka itu berarti emas itu diuji kadarnya (Ibnu Faris, 1406:711). Menafsirkan maksud kata fitnah dalam surat al ankabut, AlThobari mengatakan bahwa fitnah adalah, "اختبار و ابتلاء" (Abu Ja'far ath Thobari, $1420 \mathrm{H}$ : 19), pengujian baik melalui hal-hal yang disukai maupun hal yang disukai dan tidak disukai. Pengertian lain dari perkataan la yuftanun adalah "لأيسألون" (Al-Mawardy, tt: 275), tidak ditanya, sehingga maknanya adalah pengakuan keimanan seorang mukmin itu akan ditanyakan kebenarannya.

Al 'Askari berpendapat bahwa, fitnah adalah "اثثد الاختبار" (Abu Halal al 'Askariy, tt: 217), ujian yang sangat berat. Menjadikan sebuah kenikmatan itu sebagai sarana fitnah adalah bentuk hiperbola, sebagaimana emas meskipun secara lahiriyah merupakan kenikmatan perhiasan namun kualitas sebenarnya terlihat ketika dibakar.

Dalam ayat ini juga terkandung pengertian bahwa ujian memiliki sifat intensif atau terus menerus, bukan sesuatu yang baru atau tanpa perencanaan dan tujuan. Az Zuhaili هو سنة الله الدائمة في خلقه في " mengatakan (Wahbah bin Musthofa az Zuhailiy, 1418 H:189), ujian adalah sunnah Allah yang bersifat permanen atas ciptaan-Nya sejak masa lampau hingga masa yang akan datang. 4. Al-Bala

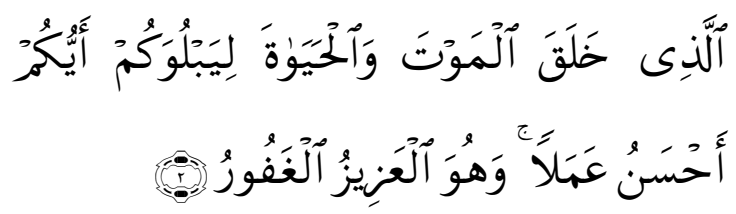

Artinya: (Dialah Allah) yang menjadikan mati dan hidup, supaya Dia menguji kamu, siapa di antara kamu yang lebih baik amalnya. dan Dia Maha Perkasa lagi Maha Pengampun, (Q.S. al-Mulk: 2).

Secara bahasa al bala berarti "الاختبار يكون بالخير والثر (Ibnu Faris, 1406:133), ujian yang bisa berupa kebaikan dan keburukan. Dalam pengertian lain "الَبَلاءُ يُكونُ مِنْحَة ويكونُ مِحْنَنَ (Murtadho Az-Zubaidy, tt:207.) bala itu bisa berupa anugerah maupun bencana. Al bala juga berarti " الاختبار "والامتحان ليعلم ما يكون من حال المختبر "(Wahbah bin Musthofa az Zuhailiy, $1418 \mathrm{H}: 38$ ), pengujian dan latihan untuk mengetahui hakikat sesuatu melalui pengalaman.

Raghib al Ashfihani membedakan ujian yang datang karena kehendak Allah dan musibah yang disebabkan oleh manusia itu sendiri. Menurutnya perbedaan tersebut bisa dilihat dari penggunaan kata balaa dan ibtalaa. Penggunaan kata balaa (menguji) dimaksudkan untuk sebuah ketetapan Allah atas hambanya, sedangkan penggunaan kata ibtalaa (mendapatkan ujian) bisa bermakna selain hal tersebut sebelumnya juga bisa bermakna orang tersebut memahami keadaan yang berlaku pada dirinya dan tidak memahami sesuatu diluas batasannya (Ashfihani, $1412 \mathrm{H}$ : 61-62).

Dari pengertian-pengertian evaluasi Allah atas manusia tersebut di 
atas baik dalam terminologi, $A l-$ Hisāb/al-Muhāsabah, Al-Hukm, al fitnah, maupun al bala memiliki tujuan untuk mengetahui hakikat dari sesuatu yang diuji, pada diri manusia berarti mengetahui respon aspek pemikiran, hati maupun sikap atau tindakan fisik atas ujian yang secara permanen diberikan baik berupa kebaikan yang disenanginya maupun keburukan yang dibencinya

Dalam arti luas makna evaluasi sebagaimana yang dikutif oleh ngalim purwanto dalm mehrens \& Lehmann, (1978), menjelaskan adalah suatu proses merencanakan, memperoleh dan menyediakan informasi yang sangat diperlukan untuk alternatifalternatif keputusan (Purwanto, 2009:3).

Evaluasi mengandung makna, sebagai alat penilaian bagi guru untuk mengetahui keberhasilan dan pencapaian tujuan setelah berlansung (Azhar, 1991: 117). Mardapi (2009: 231), evaluasi memiliki makna adanya pengumpulan informasi, penggambaran, pencarian, dan penyajian informasi guna pengambilan keputusan tentang program yang dilaksanakan. Sax (1980:18) juga berpendapat "evaluation is a process through which a value judgement or decision is made from a variety of observations and from the background and training of the evaluator" evaluasi adalah suatu proses dimana pertimbangan atau keputusan suatu nilai dibuat dari berbagai pengamatan, latar belakang serta pelatihan dari evaluator (Ismanto, 2014: 216).

Evaluasi menggunakan informasi hasil pengukuran dan penilaian. Hasil pengukuran berbentuk skor (angka) yang kemudian skor ini dinilai dan ditafsirkan berdasarkan aturan untuk ditentukan tingkat kemampuan seseorang. Hasil proses penilaian ini kemudian dilakukan evaluasi untuk menentukan tingkat keberhasilan seseorang atau suatu program. Dalam dunia pendidikan, menilai sering diartikan sama dengan melakukan evaluasi. Perbedaan antara kedua kata tersebut terletak pada pemanfaatan informasi, dimana informasi penilaian merupakan hasil pengukuran, sedangkan informasi pada evaluasi berupa nilai (Ismanto, 2014: 216).

Dari beberapa pendapat, dapat ditarik kesimpulan bahwa evaluasi yaitu suatu proses dan tindakan yang terencana untuk mengumpulkan informasi tentang kemajuan, pertumbuhan dan perkembangan (peserta didik) terhadap tujuan (pendidikan), sehingga dapat disusun penilaiannya yang dapat dijadikan dasar untuk membuat keputusan.

\section{b. Pengukuran}

Pengukuran adalah proses pemberian bilangan atau angka pada objek-objek atau sesuatu kejadian menurut aturan tertentu (Kerlinger, 1986), pengukuran terdiri dari aturanaturan tertentu untuk memberikan angka atau bilangan kepada objek dengan cara tertentu pula sehingga angka itu dapat mempresentasikan dalam bentuk kuantitatif sifat-sifat dari objek tersebut (Purnomo dan Munadi, 2005: 265-266).

Menurut Ismanto dalam Allendan Yen (1979: 2), pengukuran didefinisikan sebagai penetapan suatu angka terhadap suatu subjek dengan cara yang sistematik. Jadi pengukuran adalah memberi bentuk kuantitatif pada subjek, objek atau kejadian dengan memperhatikan aturan-aturan tertentu sehingga bentuk kuantitatif tersebut betul-betul menunjukkan keadaaan yang sebenarnya yang diukur (Ismanto, 2014: 214).

Pada hasil pengukuran yang berupa angka/skor, objek yang diukur berupa pengetahuan, sikap, dan keterampilan sebagai satu kesatuan 
yang utuh yang menunjukkan kualitas perilaku belajar dari peserta didik. Subjek dalam hal ini menunjuk pada peserta didik, objek menunjuk kepada domain hasil belajar, dan kejadian ditunjukkan oleh kualitas perilaku belajar peserta didik (Ismanto, 2014: 214).

c. Penilaian

Penilaian merupakan suatu kegiatan untuk menentukan tingkat atau derajat sesuatu objek atau kejadian yang didasarkan atas hasil pengukuran objek tersebut. Ismanto dalam Hill (1997), menjelaskan penilaian adalah kegiatan mengolah informasi yang diperoleh melalui pengukuran untuk menganalisisdan mempertimbangkan unjuk kerja peserta didik pada tugas-tugas yang relevan. Kegiatan ini juga digunakan untuk menilai materi, program, atau kebijakan-kebijakan dengan maksud untuk menetapkan nilai kelayakan peserta didik (Ismanto, 2014: 214).

Nitko (1996: 4) menjelaskan "assessment is abroadterm defined as aprocess for obtaining information that is used formaking decisions about students, curricula and programs, and educational policy" penilaian merupakan suatu proses yang dilakukan untuk mendapatkan informasi dengan tujuan mempermudah mengambil keputusan tentang peserta didik, kurikulum, program, dan kebijakan pendidikan.Jadi, penilaian pada dasarnya merupakan suatu kegiatan formal untuk menentukan tingkat atau status, penafsiran dan deksripsi hasil pengukuran hasil belajar peserta didik dibandingkan dengan aturan tertentu.

Penilaian (assessment) diartikan sebagai prosedur yang digunakan untuk mendapatkan informasi untuk mengukur taraf pengetahuan dan keterampilan subjek didik yang hasilnya akan digunakan untuk keperluan evaluasi (Subali, 2010: 3).
Penilaian pendidikan adalah proses pengumpulan dan pengolahan informasi untuk menentukan pencapaian hasil belajar peserta didik. Informasi adalah data yang diperoleh melalui pengukuran dan non pengukuran termasuk di dalamnya dengan melakukan observasi kelas, menggunakan tes yang standar atau tes buatan guru, proyek, dan portofolio subjek belajar.

Dalam UU No.20/2003 tentang Sistem Pendidikan Nasional Bab I Pasal 1 ayat 21 dijelaskan bahwa evaluasi pendidikan adalah kegiatan pengendalian, penjaminan, dan penetapan mutu pendidikan terhadap berbagai komponen pendidikan pada setiap jalur, jenjang, dan jenis pendidikan sebagai bentuk pertanggung jawaban penyelenggaraan pendidikan. Pejelasan tersebut tertuang dalam peraturan Pemerintah 19/2005 tentang Standar Nasional Pendidikan Bab I pasal 1 ayat 17 dikemukakan bahwa "penilaian adalah proses pengumpulan dan pengolahan informasi untuk mengukur pencapaian hasil belajar peserta didik (Ditjen Dikdasmen Depdiknas, 2003: 1).

Ditjen Dikdasmen Depdiknas secara eksplisit mengemukakan bahwa antara evaluasi dan penilaian mempunyai persamaan dan perbedaan. Adapun kesamaannya adalah adalah keduanya mempunyai sama-sama bermakna menilai atau menentukan nilai sesuatu. Adapun perbedaannya terletak pada konteks penggunaannya. Penilaian (assessment) digunakan dalam konteks yang lebih sempit dan biasanya dilaksanakan secara internal, yakni oleh orang-orang yang menjadi bagian atau terlibat dalam sistem yang bersangkutan, seperti guru menilai hasil belajar murid, atau supervisor menilai guru. Guru dan supervisor merupakan bahagian penting dalam sistem pendidikan. Adapun evaluasi digunakan dalam konteks yang lebih luas dan biasanya dilaksanakan secara 
eksternal, seperti konsultan yang disewa untuk mengevaluasi suatu program, baik pada level terbatas maupun pada level yang luas (Suryana, 2016: 290).

\section{TUJUAN EVALUASI PEMBELAJARAN}

Menurut Abdul Mujib dkk, tujuan evaluasi adalah:

1. Merangsang kegiatan peserta didik dalam menempuh program pendidikan. Tanpa adanya evaluasi maka tidak mungkin timbul kegairahan atau rangsangan pada peserta didik untuk memperbaiki dan meningkatkan prestasinya masing-masing

2. Mengetahui tingkat efektifitas metode yang digunakan dalam meningkatkan kemampuan pemahaman peserta didik terhadap materi pelajaran yang di pelajari, serta melatih keberanian, dan mengajak peserta didik untuk mengingat kembali materi yang telah diberikan, dan mengetahui tingkat perubahan perilakunya (Abdul Mujib \& Jusuf Mudzakir, 2008: 211).

3. Mengetahui siapa diantara peserta didik yang cerdas dan yang lemah, sehingga yang lemah diberi perhatian khusus agar ia dapat mengejar kekurangannya (Abdul Mujib \& Jusuf Mudzakir, 2008: 211).

4. Mengumpulkan informasi yang dapat dipergunakan sebagai dasar untuk mengadakan pengecekan yang sistematis terhadap hasil pendidikan yang telah dicapai untuk kemudian dibandingkan dengan tujuan yang telah ditetapkan sebelumnya (Arief, 2002: 53).

Pendapat senada mengungkapkan bahwa tujuan evaluai yaitu untuk mengetahui penguasaan peserta didik dalam kompitensi/subkompitensi tertentu setelah mengikuti proses pembelajaran, untuk mengetahui kesulitan belajar peserta didik (diagnostic test) dan untuk memberikan arah dan lingkup pengembangan eavaluasi selanjutnya. Ada tiga tujuan pedagogis dari sistem evaluasi Tuhan terhadap perbuatan manusia, (M. Arifin, 2009: 163164) yaitu:

1. Untuk menguji daya kemampuan manusia beriman terhadap berbagai macam problema kehidupan yang dialaminya.

2. Untuk mengetahui sejauhmana hasil pendidikan Islam yang telah diterapkan Rasulullah SAW. terhadap umatnya.

3. Untuk menentukan klasifikasi atau tingkat-tingkat hidup keislaman atau keimanan manusia, sehingga diketahui manusia yang paling mulia di sisi Allah SWT yaitu paling bertaqwa kepadaNya, manusia yang sedang dalam iman atau ketaqwaannya, manusia yang ingkar kepada ajaran Islam.

\section{FUNGSI DAN KEGUNAAN EVALUASI PEMBELAJARAN}

Di antara kegunaan yang dapat di ambil dari kegiatan evaluasi pendidikan dan pembelajaran di sekolah mempunyai fungsi sebagai berikut:

1. Terbukanya kemungkinan bagi evaluator guna memperoleh informasi tentang hasil-hasil yang telah dicapai dalam rangka pelaksanaan program pendidikan dan pembelajaran.

2. Untuk mengetahui peserta didik yang terpandai dan terkurang di kelasnya.

3. Untuk mendorong persaingan yang sehat antara sesama peserta didik.

4. Untuk mengetahui kemajuan dan perkembangan peserta didik setelah mengalami pendidikan dan pengajaran.

5. Untuk mengetahui tepat atau tidaknya guru memilih bahan, metode, dan berbagai penyesuaian dalam kls.

6. Sebagai laporan terhadap orang tua peserta didik dalam bentuk raport, ijazah, piagam dan sebagainya (Sudijono, 2009: 17).

Hamalik, menjelaskan bahwa fungsi evaluasi adalah untuk membantu peserta didik agar ia dapat mengubah atau mengembangkan tingkah lakunya secara sadar, serta memberi bantuan padanya 
cara meraih suatu kepuasan bila berbuat sebagaimana mestinya, selain itu juga dapat membantu seorang pendidik dalam mempertimbangkan adequate (cukup memadai) metode pengajaran serta membantu dan mempertimbangkan administrasinya (Oemar Hamalik, 1982:212).

Sementara pendapat lain mengemukakan, evaluasi berfungsi sebagai (M. Arifin, 2009: 167)

1. Mengidentifikasi dan merumuskan jarak dari sasaran-sasaran pokok dari kurikulum secara komprehensif;

2. Penetapan bagi tingkah laku apa yang harus direalisasikan oleh siswa;

3. Menyeleksi atau membentuk instrumen-instrumen yang valid, terpercaya dan praktis untuk menilai sasaran-sasaran utama proses kependidikan atau ciri-ciri khusus dari perkembangan dan pertumbuhan manusia didik.

Kemudian, secara umum ada empat kegunaan evaluasi dalam pendidikan Islam (Al-Rasyidin dkk, 2005: 77-78), diantaranya:

1. Dari segi pendidik, yaitu untuk membantu seorang pendidik mengetahui sejauhmana hasil yang dicapai dalam pelaksanaan tugasnya

2. Dari segi peserta didik, yaitu membantu peserta didik untuk dapat mengubah atau mengembangkan tingkah lakunya secara sadar ke arah yang lebih baik.

3. Dari segi ahli fikir pendidikan Islam, untuk membantu para pemikir pendidikan Islam mengetahui kelemahan teori-teori pendidikan Islam dan membantu mereka dalam merumuskan kembali teori-teori pendidikan Islam yang relevan dengan arus dinamika zaman yang senantiasa berubah.

4. Dari segi politik pengambil kebijakan pendidikan Islam, untuk membantu mereka dalam membenahi sistem pengawasan dan mempertimbangkan kebijakan yang akn diterapkan dalam sistem pendidikan nasional (Islam).

Sementara itu, sasaran evaluasi pendidikan meliputi: peserta didik dan juga pendidik untuk mengetahui sejauhmana ia bersungguh-sungguh dalam menjalankan tugasnya untuk mencapai tujuan pendidikan Islam (AlAbrasyî, t.th: 362).

Sementara menurut Abudin Nata, bahwa sasaran evaluasi yaitu untuk mengevaluasi peserta didik, pendidik, materi pendidikan, proses penyampaian materi pelajaran, dan berbagai aspek lainnya yang berkaitan dengan materi pendidikan (Abudin Nata, 308).

Sasaran-sasaran evaluasi pendidikan Islam secara garis besarnya melihat empat kemampuan peserta didik (M. Arifin, 2009:162-163) yaitu:

1. Sikap dan pengalaman terhadap hubungan pribadinya dengan Tuhannya.

2. Sikap dan pengalaman terhadap arti hubungan dirinya dengan masyarakat.

3. Sikap dan pengalaman terhadap arti hubungan kehidupannya dengan alam sekitarnya.

4. Sikap dan pandangannya terhadap diri sendiri selaku hamba Allah Swt, anggota masyarakat serta selaku khalifah-Nya di muka bumi.

5. Allah Swt. dalam mengevaluasi hambahamba-Nya tidak memandang formalitas, tetapi memandang substansi di balik tindakan hambahamba-Nya. Kualitas perilaku lebih dipentingkan daripada kualitasnya dalam proses evaluasi (Abdul Mujib \& Jusuf Mudzakir, 2008: 213).

Daging-daging unta dan darahnya itu sekali-kali tidak dapat mencapai (keridhaan) Allah, tetapi ketakwaan dari kamulah yang dapat mencapainya. Demikianlah Allah telah menundukkannya untuk kamu supaya kamu mengagungkan Allah terhadap hidayah-Nya kepada kamu. dan berilah 
kabar gembira kepada orang-orang yang berbuat baik.

\section{RUANG LINGKUP PEMBELAJARAN}

EVALUASI

Ruang lingkup evaluasi pembelajaran berkaitan dengan cakupan objek evaluasi itu sendiri. Jika objek evaluasi itu tentang pembelajaran, maka semua hal yang berkaitan dengan pembelajaran menjadi ruang lingkupnya. Oleh sebab itui yang menjadi ruang lingkup evaluasi Pembelajaran yaitu:

a. Domain hasil belajar

Menurut Benyamin S. Bloom, hasil belajar dapat dikelompokkan kedalam tiga domain, yaitu kognitif, apektif, psikomotorik. Setiap domain disusun menjadi beberapa jenjang kemampuan mulai dari yang sederhana sampai dengan hal yang kompleks, mulai dari yang mudah kepada yang sukar, dan mulai dari yang konkrit sampai dengan hal yang abstrak (Arifin, 2016: 21).

b. Sistem pembelajaran

Sebagaimana yang telah disinggung di atas, ruang lingkup evaluasi pembelajaran hendaknya bertitik tolak dari tujuan evaluasi pembelajaran itu sendiri. Jika tujuan evaluasi adalah untuk mengetahui keefektifan sistem pembelajaran, maka ruang lingkup evaluasi sebagai berikut:
a) Program pembelajaran
b) Proses pelaksanaan pembelajaran
c) Hasil belajar

c. Proses dan hasil belajar

Evaluasi mengenai proses pelaksanaan pembelajaran mencakup:

a) Kesesuain antara proses belajar mengajar yang berlangsung, dengan garis-garis besar program pengajaran yang telah ditentukan;

b) Kesiapan guru dalam melaksanakan program pengajara;

c) Kesiapan siswa dalam mengikuti proses pembelajaran;

d) Minat atau perhatian siswa yang memerlukan; e) Komunikasi dua arah antara guru dan murid selama proses pembelajaran berlangsung;

f) Pemberian motivasi atau dorongan terhadap siswa;

g) Pemberian tugas-tugas kepada siswa dalam rangka penerapan teori-teori yang diperoleh didalam kelas;

h) Upaya menghilangkan dampak negatif yang timbul sebagai akibat dari kegiatan-kegiatan yang dilakukan di sekolah (Anas Sudijono, 2009: 30).

Sedangkan evaluasi terhadap hasil belajar peserta didik mencakup:

a) Evaluasi mengenai tingkat penguasaan pesertadidik terhadap tujuan-tujuan khusus yang ingin dicapai dalam unit-unit program pengajaran yang bersifat terbatas;

b) Evaluasi mengenai tingkat pencapaian peserta didik trhadap tujuan-tujuan umum pengajaran

c) Kecerdasan pesertadidik;

d) Perkembangan jasmani dankesehatan (Sudijono, 2009: 30).

d. Kompetensi atau berbasi kelas

Sesuai dengan petunjuk pengemba ngan kurikulum, maka ruang lingkup penilaian Kompetensi atau berbasi kelas mencakup:

a) Kompetensi Dasar Mata Pelajaran;

b) Kompetensi Rumpun Pelajaran;

c) Kompetensi Lintas Kurikulum;

d) Kompetensi Tamatan;

e) Pencapaian Keterampilan Hidup; (Arifin, 2016: 27-28).

\section{PRINSIP EVALUASIPEMBELAJARAN}

Pelaksanaan evaluasi agar akurat dan bermanfaat baik bagi peserta didik, pendidik ataupun pihak yang berkepentingan, maka harus memperhatikan prinsip-prisip sebagai berikut (Ramayulis, 2008: 225-226):

1. Valid

Evaluasi mengukur apa yang seharusnya diukur dengan menggunakan jenis tes yang terpercaya 
dan shahih. Artinya ada kesesuaian alat ukur dengan fungsi pengukuran dan sasaran pengukuran.

2. Berorientasi kepada kompetensi

Dengan berpijak pada kompetensi, maka ukuran-ukuran keberhasilan pembelajaran akan dapat diketahui secara jelas dan terarah.

3. Berkelanjutan atau Berkesinambungan (kontinuitas)

Evaluasi tidak boleh dilakukan secara insidental karena pembelajaran itu sendiri adalah suatu proses yang kontinu. Oleh sebab itu Evaluasi harus dilakukan secara terus menerus dari waktu ke waktu untuk mengetahui secara menyeluruh perkembangan peserta didik, sehingga kegiatan dan unjuk kerja peserta didik dapat dipantau melalui penilaian (Arifin, 2016: 31). Dalam ajaran Islam sangatlah diperhatikan kontinuitas, karena dengan berpegang prinsip ini, keputusan yang diambil oleh seseorang menjadi valid dan stabil serta menghasilkan suatu tindakan yang menguntungkan.

4. Menyeluruh (Komprehensif)

Dalam melakukan evaluasi terhadap objek, guru harus mengambil seluruh objek itu sebagai bahan evaluasi. Evaluasi harus dilakukan secara menyeluruh, meliputi kepribadian, ketajaman hafalan, pemahaman, ketulusan, kerajinan, sikap kerja sama, tanggung jawab, dan sebagainya, atau dalam taksonomi Benjamin S. Bloom lebih dikenal dengan aspek kognitif, afektif dan psikomotor. Kemudian Anderson dan Cratwall mengembangkannya menjadi 6 aspek yaitu mengingat, mengetahui, aplikasi, analisis, kreasi dan evaluasi.

5. Bermakna

Evaluasi diharapkan mempunyai makna yang signifikan bagi semua pihak. Untuk itu evaluasi hendaknya mudah difahami dan dapat ditindaklanjuti oleh pihak-pihak yang berkepentingan.

6. Adil dan objektif

Dalam melaksanakan, guru harus berlaku adail tanpa pilih kasih. Evaluasi harus mempertimbangkan rasa keadilan bagi peserta didik dan objektif berdasarkan kenyataan yang sebenarnya, tidak boleh dipengaruhi oleh hal-hal yang bersifat emosional dan irasional. Jangan karena kebencian menjadikan ketidakobjektifan evaluasi.

Kata "adil" dan "objektif" memang mudah diucapkan, tetap sulit dilaksanakan. Meski demikian, kewajiban manusia adalah harus beriktiar. Semua peserta didik harus diberlakukan sama tanpa "pandang bulu" guru juga hendaknya bertindak secara objektif, apa adanya sesuai dengan kemampuan peserta didik. Oleh sebab itu, sikap like and dislike, perasaan, keinginan, dan prasangka yang bersifat negatif harus dijauhkan. Evaluasi harus didasarkan atans kenyataan (data dan fakta) yang sebenarnya, bukan hasil manipulasi atau rekayasa (Arifin, 2016: 31).

7. Terbuka

Evaluasi hendaknya dilakukan secara terbuka bagi berbagai kalangan sehingga keputusan tentang keberhasilan peserta didik jelas bagi pihak-pihak yang berkepentingan, tanpa ada rekayasa atau sembunyisembunyi yang dapat merugikan semua pihak.

8. Ikhlas

Evaluasi dilakukan dengan niat dan yang bersih, dalam rangka efisiensi tercapainya tujuan pendidikan dan bai kepentingan peserta didik.

9. Praktis

Praktiks mengandung arti mudah digunakan, baik guru maupun yang menyusun alat evaluasi maupun yang menggunakanalat tersebut. Oleh sebab ituEvaluasi dilakukan dengan mudah dimengerti dan dilaksanakan dengan 
beberapa indikator, yaitu: a) hemat waktu, biaya dan tenaga; b) mudah diadministrasikan; c) mudah menskor dan mengolahnya; dan d) mudah ditafsirkan

10. Dicatat dan akurat

Hasil dari setiap evaluasi prestasi peserta didik harus secara sistematis dan komprehensif dicatat dan disimpan, sehingga sewaktu-waktu dapat dipergunakan.

\section{SISTEM EVALUASI PEMBELAJARAN DALAM PENDIDIKAN ISLAM}

Sistem evaluasi yang dikembangkan dalam oleh Allah SWT dan Rasul-Nya berimplikasikan paedagogis sebagai berikut (Abdul Mujib \& Jusuf Mudzakir, 2008: 163-164):

1. Untuk menguji daya kemampuan manusia beriman terhadap berbagai macam problema kehidupan yang dihadapi. Seperti tercantum dalam QS. Al-Baqarah: 155

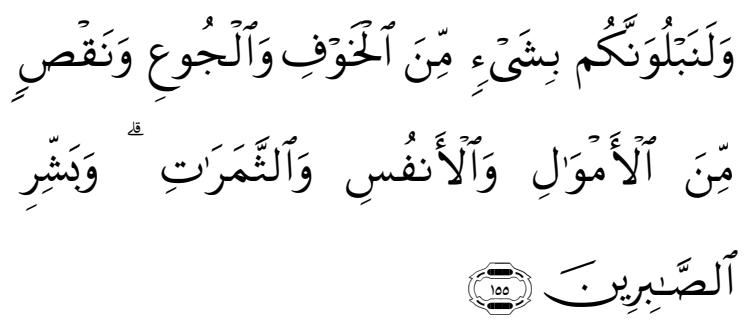

Artinya: "dan sungguh akan Kami berikan cobaan kepadamu, dengan sedikit ketakutan, kelaparan, kekurangan harta, jiwa dan buahbuahan. dan berikanlah berita gembira kepada orang-orang yang sabar"

2. Untuk mengetahui sejauhmana hasil pendidikan wahyu yang telah diaplikasikan Rasulullah SAW kepada umatnya. Seperti tercantum dalam QS. An-Naml: 40:

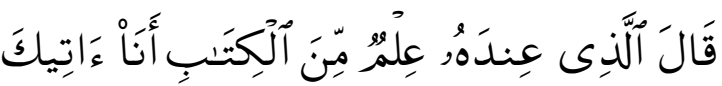

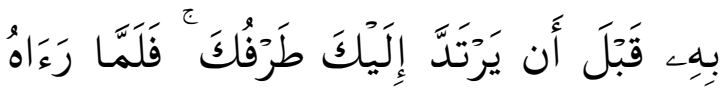

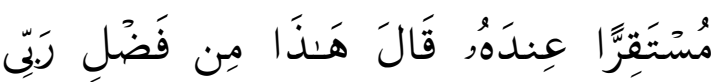

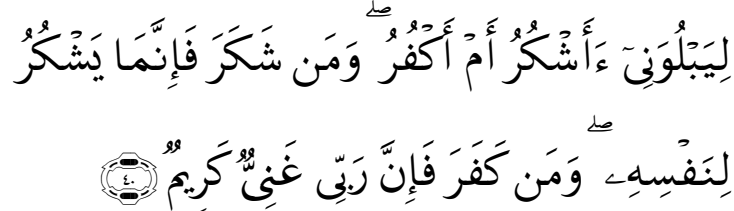

Artinya: "berkatalah seorang yang mempunyai ilmu dari AI Kitab: "Aku akan membawa singgasana itu kepadamu sebelum matamu berkedip". Maka tatkala Sulaiman melihat singgasana itu terletak di hadapannya, iapun berkata: "Ini Termasuk kurnia Tuhanku untuk mencoba aku Apakah aku bersyukur atau mengingkari (akan nikmat-Nya). dan Barangsiapa yang bersyukur Maka Sesungguhnya Dia bersyukur untuk (kebaikan) dirinya sendiri dan Barangsiapa yang ingkar, Maka Sesungguhnya Tuhanku Maha Kaya lagi Maha Mulia". Juga seperti pengevaluasian Nabi Sulaiman terhadap burung hud-hud, seperti tercantum dalam QS. Al-Naml ayat 27:

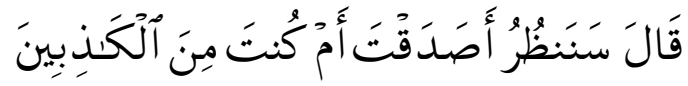

Artinya: "berkata Sulaiman: "Akan Kami lihat, apa kamu benar, ataukah kamu Termasuk orang-orang yang berdusta."

3. Untuk menentukan klasifikasi atau tingkat hidup keislaman atau keimanan seseorang, seperti pengevaluasian Allah Swt terhadap Nabi Ibrahim yang menyembelih Ismail putera yang dicintainya. Seperti tercantum dalam QS. As-Shaffat ayat 103-107:
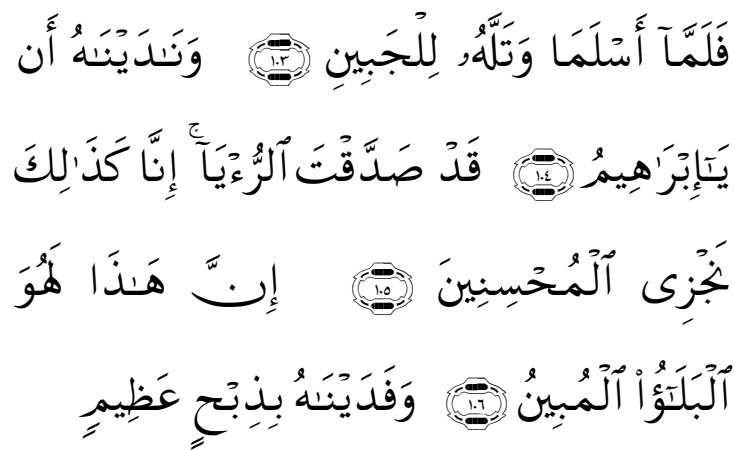

Artinya: "tatkala keduanya telah berserah diri dan Ibrahim membaringkan anaknya atas pelipis(nya), (nyatalah kesabaran 
keduanya). Dan Kami panggillah dia: "Hai Ibrahim, Sesungguhnya kamu telah membenarkan mimpi itu. Sesungguhnya Demikianlah Kami memberi Balasan kepada orang-orang yang berbuat baik. Sesungguhnya ini benar-benar suatu ujian nyata. Dan Kami tebus anak itu dengan seekor sembelihan yang besar.

4. Untuk mengukur daya kognisi, hafalan manusia dari pelajaran yang telah diberikan pdnya, seperti pengevaluasian terhadap Nabi Adam tentang asma-asma yang diajarkan Allah Swt kepadanya di hadapan para malaikat, seperti tercantum dalam QS. Al-Baqarah ayat 31:
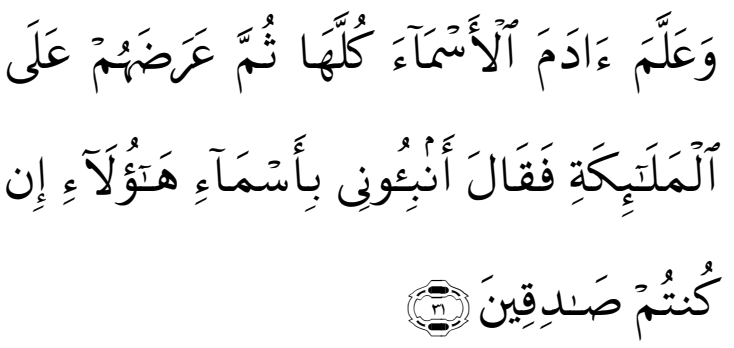

Artinya: "dan Dia mengajarkan kepada Adam nama-nama (benda-benda) seluruhnya, kemudian mengemukakannya kepada Para Malaikat lalu berfirman: "Sebutkanlah kepada-Ku nama benda-benda itu jika kamu mamang benar orang-orang yang benar!".

5. Memberikan semacam tabsyîr (berita gembira) bagi yang beraktivitas baik, dan memberikan semacam iqab (siksa) bagi yang beraktivitas buruk, seperti tercantum dalam QS. Al-Zalzalah ayat 7-8:

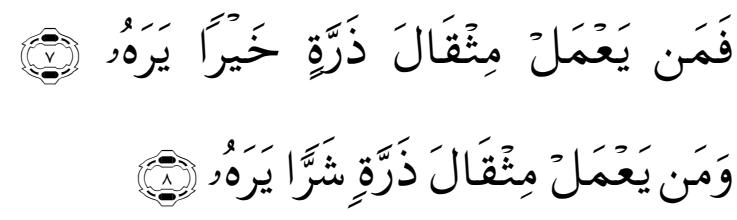

Artinya: "Barangsiapa yang mengerjakan kebaikan seberat dzarrahpun, niscaya Dia akan melihat (balasan)nya. Dan Barangsiapa yang mengerjakan kejahatan sebesar dzarrahpun, niscaya Dia akan melihat (balasan)nya pula.

\section{JENIS-JENIS EVALUASI DALAM PEMBELAJARAN}

Dilihat dari pengertian, tujuan, fungsi dan ruang lingkup sistem pembelajaran, maka pada hakekatnya pembelajaran adalah adalah suatu program. Artinya evaluasi yang digunakan dalam pembelajaran adalah evaluasi penilaian hasil belajar. Zainal Arifin (2016: 35-36) menjelaskan ada empat jenis evaluasi penilaian hasil belajar yang dapat digunakan. Yakni penilaian formatif, penilaian sumatif, penempatan dan penilaian diagnostik. Hal senada juga dikemukanan Yahya Qahar, (t.th: 14-210). Jenis-jenis evaluasi yang dapat diterapkan dalam pendidikan Islam adalah:

1. Evaluasi Formatif, yaitu penilaian untuk mengetahui dan memantau kemajuan hasil belajar yang dicapai oleh para peserta didik selama proses belajar berlangsung dan setelah menyelesaikan satuanprogram pembelajaran (kompetensi dasar) pada mata pelajaran tertentu, serta untuk mengetahui kelemahan-kelemahan yang memerlukan perbaikan, sehingga hasil belajar peserta didik dan proses belajar guru menjadi lebih baik.Tujuan utama penilaian formatif adalah untuk memperbaiki proses pembelajaran, bukan untuk menentukan tingkat kemampuan peserta didik. Jenis ini diterapkan berdasarkan asumsi bahwa manusia memiliki banyak kelemahan seperti tercantum dalam QS. An-Nisa ayat 28 "Allah hendak memberikan keringanan kepadamu, dan manusia dijadikan bersifat lemah". Dan pada mulanya tidak mengetahui apa-apa, tercantum dalam QS. An-Nahl: 78, sehingga pengetahuan, ketrampilan, dan sikap itu tidak dibiasakan. "Dan Allah mengeluarkan kamu dari perut ibumu dalam keadaan tidak mengetahui sesuatupun, dan Dia memberi kamu pendengaran, penglihatan dan hati, agar kamu bersyukur".Untuk itu Allah SWT 
menganjurkan agar manusia berkonsentrasi pada suatu informasi yang didalami sampai tuntas, mulai proses pencarian, (belajar mengajar) sampai pada tahap pengevaluasian. Setelah informasi itu dikuasai dengan sempurna, ia dapat beralih pada informasi yang lain, tercantum dalam QS. Al-Insyirah: 7-8. "Maka apabila kamu telah selesai (dari sesuatu urusan), kerjakanlah dengan sungguhsungguh (urusan) yang lain, dan hanya kepada Tuhanmulah hendaknya kamu berharap".

a. Fungsi, yaitu untuk memperbaiki proses pembelajaran ke arah yang lebih baik dan efisien atau memperbaiki satuan/rencana pembelajaran.

b. Tujuan, yaitu untuk mengetahui penguasaan peserta didik tentang materi yang diajarkan dalam satu satuan/rencana pembelajaran.

c. Aspek yang dinilai, terletak pada penilaian normatif yaitu hasil kemajuan belajar peserta didik yang meliputi: pengetahuan, keterampilan dan sikap terhadap materi ajar PAI yang disajikan.

d. Waktu pelaksanaan : akhir kegiatan pembelajaran dalam satu satuan/rencana pembelajaran.

2. Evaluasi Sumatif, istilah "sumatif" berasal dari kata "sum" yang berarti "total obtained by adding together items, numbers or amounst, yaitu evaluasi yang dilakukan terhadap hasil belajar peserta didik setelah mengikuti pelajaran dalam satu semester dan akhir tahun untuk menentukan jenjang berikutnya, seperti tercantum dalam QS. Al-Insyiqaq ayat 19 "Sesungguhnya kamu melalui tingkat demi tingkat (dalam kehidupan). Dan juga dalam QS. Al-Qamar ayat 49 yaitu "Sesungguhnya Kami menciptakan segala sesuatu menurut ukuran."

Dengan demikian, ujian akhir semester dan ujian nasional termasuk penilaian Sumatif. Penilaian sumatif diberikan dengan maksud untuk mengetahui apakah peserta didik sudah dapat menguasai standar kompetensi yang telah ditetapkan atau belum. Tujuan penelian sumatif adalah untuk menentukan nilai (angka) berdasarkan tingkatan hasil belajar peserta didik yang selanjutnya dipakai sebagai angka rapor. Oleh sebab itu evaluasi dilakukan mengacu dan pada:

a. Fungsi, yaitu untuk mengetahui angka atau nilai peserta didik setelah mengikuti program pembelajaran dalam satu catur wulan, semester atau akhir tahun.

b. Tujuan, untuk mengetahui hasil belajar yang dicapai oleh peserta didik setelah mengikuti program pembelajaran dalam satu catur wulan, semester atau akhir tahunpada setiap mata pelajaran (PAI) pada satu satuan pendidikan tertentu.

c. Aspek-aspek yang dinilai, yaitu kemajuan hasil belajar meliputi pengetahuan, ketrampilan, sikap dan penguasaan peserta didik tentang mata pelajaran yang diberikan.

d. Waktu pelaksanaan, yaitu setelah selesai mengikuti program pembelajaran selama satu catur wulan, semester atau akhir tahun pembelajaran pada setiap mata pelajaran (PAI) pada satu tingkat satuan pendidikan.

3.Evaluasi penempatan (placement), yaitu evaluasi tentang peserta didik untuk kepentingan penempatan di dalam situasi belajar yang sesuai dengan kondisi peserta didik.

a. Fungsi, yaitu untuk mengetahui keadaan peserta didik termasuk keadaan seluruh pribadinya, sehingga peserta didik tersebut dapat ditempatkan pada posisi sesuai dengan potensi dan kapasitas dirinya. 
b. Tujuan, yaitu untuk menempatkan peserta didik pada tempat yang sebenarnya, berdasarkan bakat, minat, kemampuan, kesanggupan, serta keadaan diri peserta didik sehingga peserta didik tidak mengalami hambatan yang berarti dalam mengikuti pelajaran atau setiap program bahan yang disajikan guru.

c. Aspek-aspek yang dinilai, meliputi keadaan fisik, bakat, kemampuan, pengetahuan, pengalaman keterampilan, sikap dan aspek lain yang dianggap perlu bagi kepentingan pendidikan peserta didik selanjutnya.

d. Waktu pelaksanaan, sebaiknya dilaksanakan sebelum peserta didik menempati/menduduki kelas tertentu, bisa sewaktu penerimaan murid baru atau setelah naik kelas.

4.Evaluasi Diagnostik, yaitu evaluasi yang dilakukan terhadap hasil penganalisaan tentang keadaan belajar peserta didik, baik merupakan kesulitan-kesulitan maupun hambatan-hambatan yang ditemui dalam situasi belajar mengajar:

a. Fungsi, yaitu untuk mengetahui masalah-masalah yang diderita atau mengganggu peserta didik, sehingga peserta didik mengalani kesulitan, hambatan atau gangguan ketika mengikuti program pembelajaran dalam satu mata pelajaran tertentu (PAI). Sehingga kesulitan peserta didik tersebut dapat diusahakan pemecahannya.

b. Tujuan, yaitu untuk membantu kesulitan atau mengetahui hambatan yang dialami peserta didik waktu mengikuti kegiatan pembelajaran pada satu mata pelajaran tertentu (PAI) atau keseluruhan program pembelajaran.

c. Aspek-aspek yang dinilai, meliputi hasil belajar, latar belakang kehidupannya, serta semua aspek yang berkaitan dengan kegiatan pembelajaran.

d. Waktu pelaksanaan, disesuaikan dengan keperluan pembinaan dari suatu lembaga pendidikan, dalam rangka meningkatkan mutu pendidikan para peserta didiknya.

\section{LANGKAH-LANGKAH EVALUASI}

\begin{tabular}{llr}
\multicolumn{1}{c}{ Secara } & umum, proses \\
pengembangan & penyajian dan \\
pemanfaatan evaluasi belajar dapat & digambarkan dalam langkah-langkah \\
berikut (Ramayulis, 2008: 225-226) :
\end{tabular}

1. Penentuan Tujuan Evaluasi

2. Penyususnan Kisi-kisi soal

3. Telaah atau review dan revisi soal

4. Uji Coba (try out)

5. Penyusunan soal

6. Penyajian tes

7. Scorsing

8. Pengolahan hasil tes

9. Pelaporan hasil tes

10. Pemanfaatan hasil tes

\section{PENUTUP}

Dari uraian di atas tentang evaluasi pendidikan Islam dapat ditarik kesimpulan : Evaluasi adalah suatu proses dan tindakan yang terencana untuk mengumpulkan informasi tentang kemajuan, pertumbuhan dan perkembangan (peserta didik) terhadap tujuan (pendidikan), sehingga dapat disusun penilaiannya yang dapat dijadikan dasar untuk membuat keputusan. Evaluasi pendidikan Islam adalah suatu proses dan kegiatan penilaian yang terencana terhadap peserta didik dari keseluruhan aspek mental-psikologis dan spiritual religius dalam pendidikan Islamuntuk mengetahui taraf kemajuan dalam pendidikan Islam.

Tujuan Evaluasi yaitu: a) mengetahui kadar pemahaman peserta didik; b) mengetahui siapa diantara peserta didik yang cerdas dan yang lemah; c) mengumpulkan informasi; d) untuk mengetahui penguasaan peserta didik 
dalam kompetensi/subkompetensi tertentu; e) untuk mengetahui kesulitan belajar peserta didik (diagnostic test) dan untuk memberikan arah dan lingkup pengembangan evaluasi selanjutnya.

Evaluasi dalam pendidikan Islam, secara umumsangat berguna bagi pendidik, peserta didik, ahli fikir pendidikan Islam,politik pengambil kebijakan pendidikan Islam, untuk membantu mereka dalam membenahi sistem pengawasan dan mempertimbangkan kebijakan yang akan diterapkan dalam sistem pendidikan nasional (Islam). Adapun Sasaran evaluasi yaitu untuk mengevaluasi peserta didik, pendidik, materi pendidikan, proses penyampaian materi pelajaran, dan berbagai aspek lainnya yang berkaitan dengan materi pendidikan.

Sedangkan Prinsip Evaluasi, yaitu : valid, berorientasi kepada kompetensi, berkelanjutan/Berkesinambungan

kontinuitas), menyeluruh (Komprehensif), bermakna, adil dan objektif, terbuka, ikhlas, praktis, dicatat dan akurat.

Sistem Evaluasi Pendidikan Islam, yaitu untuk menguji daya kemampuan manusia beriman terhadap berbagai macam problema kehidupan yang dihadapi, untuk mengetahui sejauhmana hasil pendidikan wahyu yang telah diaplikasikan Rasulullah SAW kepada umatnya, untuk menentukan klasifikasi atau tingkat hidup keislaman atau keimanan seseorang, seperti pengevaluasian Allah SWT terhadap Nabi Ibrahim yang menyembelih Ismail putera yang dicintainya, untuk mengukur daya kognisi, hafalan manusia dari pelajaran yang telah diberikan padanya, seperti pengevaluasian terhadap Nabi Adam tentang asma-asma yang diajarkan Allah SWT kepadanya di hadapan para malaikat, serta memberikan semacam tabsyîr (berita gembira) bagi yang beraktivitas baik, dan memberikan semacam iqab (siksa) bagi mereka yang beraktivitas buruk.[] 


\section{DAFTAR RUJUKAN}

Al Mawardi. an Nukat wal Uyun, Beirut: Daar al Kutub al 'Ilmiyyah,Vol 4, t.th.

Al'Askariy, Abu Halal. Al Furuq al Lughawiyah, Mesir : Daar al 'Ilm wa ats Tsaqafah,t.th

Allen, M.J. danYen, W.M. Introductionto Measurement Theory, Monterey: Wardsworth, Inc, 1979.

Al-Rasyidin, dkk. Filsafat Pendidikan Islam Pendekatan Historis, teoritis dan Praktis, Jakarta: Ciputat Press, 2005.

Arief, Armai. Pengantar Ilmu dan Metodologi Pendidikan Islam, Jakarta: Ciputat Pers, 2002.

Arifin, M. Ilmu Pendidikan Islam, Tinjauan Teoritis dan Praktis Berdasarkan Pendekatan Interdisipliner, Jakarta: Bumi Aksara, 2009.

Arikunto, Suharsimi, Dasar-dasar Evaluasi Pendidikan, Jakarta: Bumi Aksara, 1990.

Ath-Thobari, Abu Ja'far. Jami'ul Bayan fi Ta'wil al Qur'an, Beirut: Muassasatu ar Risalah, Vol. $71420 \mathrm{H}$.

AzZubaidy. Murtadho, Taaj al Arus min Jawahir al Qamus, Daar alHidayah, Vol 37 , t.th.

Az-Zuhailiy. Wahbah bin Musthofa, at Tafsir al Munir fil Aqidati wasy Syari'ati wal Manhaj, Damaskus: Daar al Fikr al Muashir, Vol. 20,1418 H.

Echols, John M. dan Hassan Shadily, Kamus Inggris-Indonesia.

Faris, Ibnu. Mujmal al Lughah li Ibni Faris, Beirut: Muassasatu ar Risalah, 1406 $\mathrm{H}$.

Hamalik, Oemar. Pengajaran Unit, Bandung: Alumni, 1982.

Ismanto. Evaluasi Hasil Belajar Pendidikan Agama Islam (PAI), Edukasi: Jurnal Penelitian Pendidikan Islam. Vol. 9, No. 2, Agustus 2014.

Langgulung, Hasan. Manusia dan Pendidikan Suatu Analisa Psikologi dan Pendidikan, Jakarta: Pustaka AlHusna, 1989.
Mardapi, Djemari. Evaluasi Penerapan Ujian Akhir Sekolah Dasar Berbasis Standar Nasional, Jurnal Penelitian dan Evaluasi Pendidikan Tahun 13, Nomor 2, 2009.

Mujib, Abdul \& Jusuf Mudzakir. Ilmu Pendidikan Islam, Jakarta: Kencana, 2008.

Nata, Abudin. Filsafat Pendidikan Islam, Jakarta: Gaya Media Pratama, 2005.

Nitko, A.J. Educational Assessment of Students, New Jersey: Englewood Cliffs, 1996.

Purnomo, Edy, dan Sudji Munadi. "Evaluasi Hasil Belajar dalam Implementasi Kurikulum Berbasis Kompetensi di Sekolah Menengah Kejuruan." Cakrawala Pendidikan 2, 2005.

Purwanto, M. Ngalim. Prinsip-Prinsip Evaluasi Pengajaran, Bandung: PT. Remaja Rosda Karya, 2009.

Raghib, Al-Ashfihani, al-Mufradat fi Gharib al Qur'an, Damaskus: Daar a Qalam, $1412 \mathrm{H}$.

Ramayulis. Ilmu Pendidikan Islam, Jakarta:Kalam Mulia, 2008.

Ramayulis. Metodologi Pendidikan Agama Islam, Jakarta: Kalam Mulia, tt.

Sax, G. Principles of Educational and Psychological Measurementand Evaluation. Belmont California: Wads Worth Pub.Co, 1980.

Subali, Bambang. Penilaian, Evaluasi,dan Remediasi Pembelajaran Biologi. Yogyakarta: Jurusan Biologi Fakultas MIPA, 2010.

Sudijono, Anas. Pengantar Evaluasi Pendidikan, Jakarta: PT Raja Grafindo, 2009.

Thaha, M. Chabib. Tehnik-tehnik Evaluasi Pendidikan, Jakarta: PT Raja Grafindo, 1990.

Zuhairini. Metodik Khusus pendidikan Agama, Surabaya: Usaha Nasional, 1981. 